\title{
Apple Proteins that Interact with DspA/E, a Pathogenicity Effector of Erwinia amylovora, the Fire Blight Pathogen
}

\author{
Xiangdong Meng, Jean M. Bonasera, Jihyun F. Kim, Riitta M. Nissinen, and Steven V. Beer \\ Department of Plant Pathology, Cornell University, Ithaca, NY 14853, U.S.A.
}

Submitted 23 July 2005. Accepted 9 October 2005.

\begin{abstract}
The disease-specific ( $d s p)$ gene $d s p A / E$ of Erwinia amylovora encodes an essential pathogenicity effector of $198 \mathrm{kDa}$, which is critical to the development of the devastating plant disease fire blight. A yeast two-hybrid assay and in vitro protein pull-down assay demonstrated that $\mathrm{DspA} / \mathrm{E}$ interacts physically and specifically with four similar putative leucine-rich repeat (LRR) receptor-like serine/threonine kinases (RLK) from apple, an important host of $E$. amylovora. The genes encoding these four DspA/E-interacting proteins of Malus $\times$ domestica (DIPM1 to 4) are conserved in all genera of hosts of $E$. amylovora tested. They also are conserved in all cultivars of apple tested that range in susceptibility to fire blight from highly susceptible to highly resistant. The four DIPMs have been characterized, and they are expressed constitutively in host plants. In silico analysis indicated that the DIPMs have similar sequence structure and resemble LRR RLKs from other organisms. Evidence is presented for direct physical interaction between DspA/E and the apple proteins encoded by the four identified clones, which may act as susceptibility factors and be essential to disease development. Knowledge of DIPMs and the interaction with $\operatorname{DspA} / E$ thus may facilitate understanding of fire blight development and lead to new approaches to control of disease.
\end{abstract}

Fire blight is a devastating disease of apple, pear, and other economically important members of the family Rosaceae. The causative organism, Erwinia amylovora, is a gram-negative bacterium armed with a type III secretion system located on a pathogenicity island (Oh et al. 2005). Genes of this island encode proteins that are involved in pathogenicity and virulence. These include structural proteins for the type III secretion apparatus as well as regulatory and secreted effector proteins. One such effector protein, disease-specific (Dsp)A/E, is absolutely required for pathogenicity on apple and pear (Bogdanove et al. 1998b; Gaudriault et al. 1997). In spite of the important

Corresponding author: S. V. Beer; E-mail: svb1@ cornell.edu; Telephone: +1.607 .255 .7870 ; Fax: +1.607.255.4471.

Present address of X. Meng: Program in Gene Function and Expression, UMass Medical School, University of Massachusetts, 364 Plantation Street, Worcester, MA 01605, U.S.A.

Present address of J. F. Kim: Laboratory of Microbial Genomics, Genome Research Center, Korea Research Institute of Bioscience and Biotechnology (KRIBB), PO Box 115, Yuseong, Daejeon 305-600, Republic of Korea.

Present address of Riitta M. Nissinen: Department of Applied Biology, Laboratory of Plant Pathology, 00014 Helsinki University, Helsinki, Finland. role of DspA/E as a pathogenicity determinant in E. amylovora, little is known of its mechanism of action. It is a large protein $(198 \mathrm{kDa})$ that is secreted via the type III secretion pathway under appropriate conditions (Bogdanove et al. 1998a,b; Gaudriault et al. 1997). Recent evidence indicates that DspA/E is translocated from the bacterial cytoplasm to the plant cytoplasm via the type III secretion system (Bocsanczy et al. in press). The protein is a homolog of the avirulence (Avr) protein AvrE from the bacterial speck pathogen, Pseudomonas syringae pv. tomato (Bogdanove et al. 1998b; Gaudriault et al. 1997). It can serve as an Avr protein when it is expressed in $P$. syringae pv. glycinea and inoculated in soybean, a susceptible host (Bogdanove et al. 1998b).

$A v r$ gene products elicit rapid defense responses in host plants with corresponding resistance $(R)$ genes that lead to disease resistance. It is well established that Avr proteins are secreted and delivered into host plant cells by bacterial type III secretion systems (Galán and Collmer 1999). Recognition or interaction between Avr proteins and $R$ gene products leads to plant resistance, whereas failure of recognition or interaction contributes to pathogen virulence and proliferation in the hosts (Abramovitch and Martin 2004; Nimchuk et al. 2003). Although gene-for-gene specificity has been widely demonstrated, direct physical interaction at the molecular level between Avr proteins and $R$ gene products has been reported in only three cases: Pto and AvrPto (Scofield et al. 1996; Tang et al. 1996), Pi-ta and Avr-Pita (Jia et al. 2000), and RRS1-R and PopP2 (Deslanders et al. 2003). Recognition and signaling pathways leading to resistance likely involve several additional players (Greenberg and Vinatzer 2003; Salmeron et al. 1996; van der Biezen and Jones 1998). Abundant evidence exists to suggest that interactions among Avr, R, and other host gene products trigger intraand intercellular signaling cascades and lead to host defense response and resistance (Dangl and Jones 2001; Kjemtrup et al. 2000; Lahaye and Bonas 2001; Nimchuk et al. 2003; Torii 2000; Zhou et al. 1995).

Some avr genes also contribute to virulence of pathogens attacking susceptible plants that lack the corresponding $R$ genes (Chen et al. 2000, 2004; Lorang et al. 1994; Ritter and Dangl 1995). These two seemingly opposing functions led to the proposal of a bifunctional role for $a v r$ genes as both avirulence and virulence determinants (Bogdanove et al. 1998b; Chang et al. 2004; Chen et al. 2004; Chisholm et al. 2005; Jackson et al. 1999; Kjemtrup et al. 2000; Mackey et al. 2002, 2003; Shan et al. 2000; White et al. 2000). Although much is known of the Avr function of these genes, little is known of the virulence function or the corresponding host genes that lead to disease development. Several authors recently suggested that a molecular "arms race" is underway between plants and bacteria (Innes 2001, 
2004; Stahl and Bishop 2000). In the apple-E. amylovora race, the bacterium is the clear winner. To date, there has been no report of gene-for-gene resistance in this pathosystem (Norelli et al. 1984). Clearly, DspA/E, with its requisite role in pathogenicity and its apparent function as an Avr protein in nonhosts, seems to play a key role in this battle. Using a yeast two-hybrid screen, we set out to identify the molecular target of DspA/E in the host plant, apple. We report here the identification of four similar DspA/E-interacting proteins, their distribution in selected hosts and nonhosts, and their expression in apple.

\section{RESULTS}

Yeast two-hybrid screen for DspA/E-interacting proteins.

The entire open reading frame of $d s p A / E(5.5 \mathrm{~kb})$ and the 2.9-kb $5^{\prime}$ portion of $d s p A / E$, were fused, in frame, to the C-terminus of the DNA binding domain of LexA in the "bait" plasmid pGilda. The fusions were transformed into yeast strain EGY48 containing two reporter genes, LexAop-Leu and LexAop-lacZ (Gyuris et al. 1993). Plasmid pGilda-5.5dspA/E (DspA/E) and pGilda-2.9dspA/E (DspA/E') did not activate transcription of either of the two reporter genes (data not shown). Yeast cells containing pGilda-5.5dspA/E did not grow in inducing medium; however, these cells grew well under noninducing conditions (data not shown). Thus, it was not possible to use full-length $\mathrm{DspA} / \mathrm{E}$ as bait to identify interacting

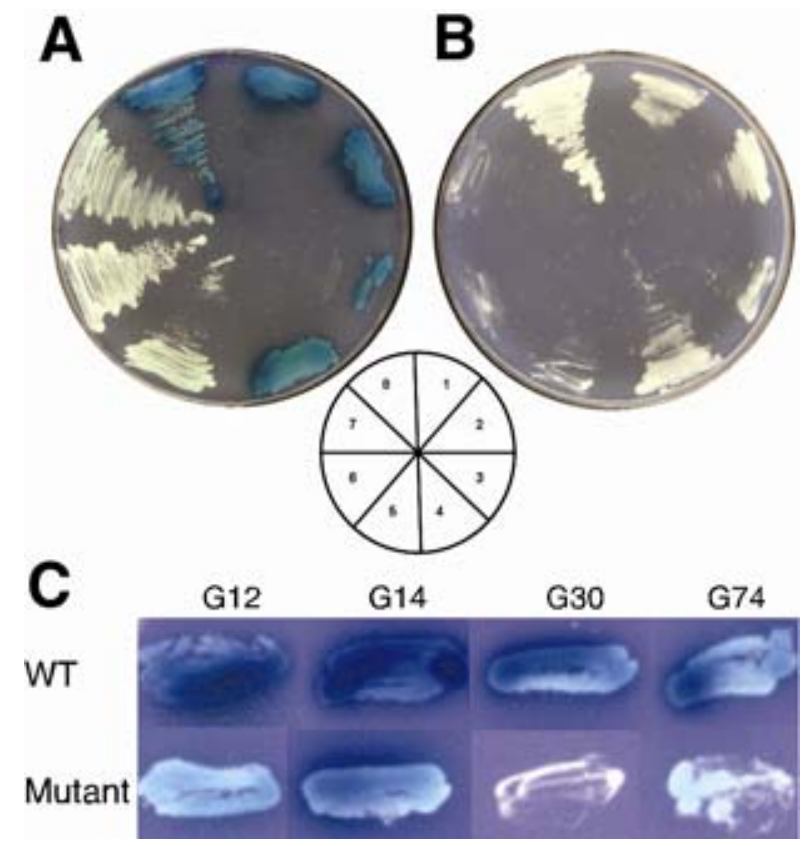

Fig. 1. Interaction between $D s p A / E^{\prime}$ and apple proteins. A, Yeast harboring the respective plasmids grown on inducing medium of X-Gal/Gal/Raf/ -Ura-Trp for expression of lacZ (blue color). B, Yeast harboring the respective plasmids grown on inducing medium of Gal/Raf/-Ura-Trp-Leu for expression of leu2. Prey and bait combinations: 1, G12 in pB42AD + $d s p A / E 2.9 \mathrm{~N}$-terminal in pGilda; $2, \mathrm{G} 14$ in $\mathrm{pB} 42 \mathrm{AD}+d s p A / E 2.9 \mathrm{~N}$-terminal in pGilda; $3, \mathrm{G} 30$ in $\mathrm{pB} 42 \mathrm{AD}+d s p A / E 2.9 \mathrm{~N}$-terminal in pGilda; 4, $\mathrm{G} 74$ in pB42AD + $d s p A / E 2.9 \mathrm{~N}$-terminal in pGilda; 5, G12 in pB42AD + pGilda (empty); 6, pB42AD (empty) $+d s p A / E 2.9$ N-terminal in pGilda; 7, G12 in pB42AD + avrE 2.8 N-terminal in pGilda; 8, Positive control (pLex53 + pB42AD-T, Clontech). C, Yeast harboring the plasmid pB42AD containing the respective identified apple proteins in both the wild types or mutations of Lys to Asn in subdomain II and pGilda containing $d s p A / E 2.9 \mathrm{~N}$-terminal grown on inducing medium of $\mathrm{X}-\mathrm{Gal} / \mathrm{Gal} / \mathrm{Raf} /-$ Ura-Trp-Leu for expression of both lacZ and leu2. Yeast strain EGY48 was transformed with reporter plasmid and corresponding bait or prey plasmids for the interaction assay. Each transformation was repeated three or more times and six or more colonies were re-screened from each transformation with similar results. proteins with the yeast two-hybrid assay. A repression assay (Golemis et al. 1997) confirmed that the LexA-DspA/E' fusion protein entered the yeast nucleus (data not shown).

From the first $10^{8}$ members of the cDNA library screened, 198 blue colonies were recovered after 5 days on selective plates. Restreaking, screening of descriptive digests, and sequencing reduced the initial 198 clones to just four distinct cDNA inserts, which interacted with the N-terminal 967 amino acids of DspA/E. The four distinct clones were named G12, G14, G30, and G74 (Fig. 1). In order to determine the specificity of interaction, the four clones were retransformed into yeast and tested for autoactivation of the reporter genes. Also, two-hybrid assays were carried out with several different baits. Expression of the DspA/E'-interacting proteins alone in yeast did not activate transcription of the reporter genes (data not shown). In addition, neither co-expression of each of the four clones in the prey vector with empty bait vector pGilda or the 2.8-kb 5' end of $a v r E$ activated reporter gene transcription (Fig. 1A and B). DspA/E' failed to interact with Xa21 in a Gal4 yeast two-hybrid assay (data not shown) (He et al. 2000; Song et al. 1995). In contrast, co-expression of any of the four prey clones and the $\mathrm{DspA} / \mathrm{E}^{\prime}$ bait protein in EGY48 consistently resulted in cleavage of X-Gal (Fig. 1A) and leucine prototrophy (Fig. 1B). Both phenotypes were dependent on growth in the inducing medium, indicating that expression of the identified apple cDNA was required for the activation of the reporter genes. Additional screens using different fragments of the $d s p A / E$ gene revealed that the apple proteins could interact with the protein encoded by the $4.67-\mathrm{kb} 5^{\prime}$ end portion of $d s p A / E$, but could not interact with the protein encoded by the 2.4-kb 3' end of $d s p A / E$ (data not shown).

\section{Apple proteins interact with DspA/E in vitro.}

Interaction between the apple proteins and $\mathrm{DspA} / \mathrm{E}$ was confirmed in vitro by using a pull-down assay. The four cDNA fragments initially identified by yeast two-hybrid analysis were expressed in Escherichia coli as T7•Tag fusion proteins. Fusion proteins were bound to $\mathrm{T} 7 \bullet$ Tag antibody agarose beads and used to capture DspA/E from the cell lysate of Escherichia coli expressing either full-length $d s p A / E$ or $d s p A / E^{\prime}$. Captured proteins were resolved by sodium dodecyl sulfate polyacrylamide gel electrophoresis (SDS-PAGE), blotted and detected using DspA/E antibody and T7 $\bullet$ Tag monoclonal antibody, respectively. The DspA/E antibody did not bind to any proteins in lanes loaded with eluate from T7•Tag antibody agarose beads or from the cell lysate from the empty vector construct. Both the DspA/E and the T7•Tag antibodies bound to proteins of the appropriate size (DspA/E' is approximately $120 \mathrm{kDa}$ ) from the cell lysate of Escherichia coli expressing the truncated $d s p A / E$ (Fig. 2). Both the N-terminal fragment and the full-length DspA/E were captured by the apple proteins (fulllength DspA/E pull-down assay data not shown).

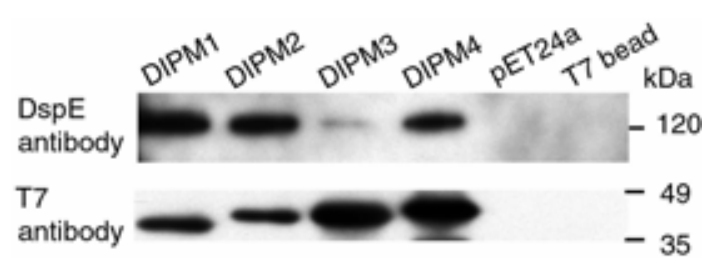

Fig. 2. In vitro (pull-down assay) interaction between apple proteins encoded by the identified clones and DspA/E'. T7 $\bullet$ Tag fused DspA/E-interacting proteins of Malus spp. (DIPMs) 1 to 4 bound to T7•Tag agarose beads were used to pull down the N-terminal fragment of DspA/E contained in cell lysates. Then, the bound proteins were eluted, resolved on sodium dodecyl sulfate polyacrylamide gel electrophoresis, Western blotted, and detected by antibodies raised in response to DspA/E and T7 $\bullet$ Tag, respectively. 
Isolation and characterization of the identified apple genes.

The cDNA fragments originally isolated from the library each contained approximately $1,200 \mathrm{bp}$ of sequence between the first nucleotide and the polyA tail. The fragments did not include a start codon and were approximately $1,100 \mathrm{bp}$ shorter than the 2.2- to 2.4-kb transcripts detected by northern hybridization; therefore, the 5' RACE procedure was used to isolate the $5^{\prime}$ termini of the four genes. There was approximately 1.1 $\mathrm{kb}$ of additional sequence in the $5^{\prime}$ termini of all four isolated cDNAs. The structure of the open reading frames encoded by the four isolated genes is shown in Figure 3A. The four proteins were designated DspA/E-interacting protein of Malus $\times$ domestica Borkh. (DIPM) 1 to 4 to correspond to the initially identified partial cDNA clones of G12, G14, G30, and G74. The four open reading frames of DIPM1, 2, 3, and 4 encode putative polypeptides of $666,676,665$, and 682 amino acids with molecular masses of 72.9,73.1, 73.2, and $74.4 \mathrm{kDa}$, respectively. The entire sequences have been deposited in GenBank as accession numbers DQ184948, DQ184949, DQ184950, and DQ184951, respectively.
Analysis of the protein sequence predicted that the DIPM proteins contain an $\mathrm{N}$-terminal signal peptide followed by a leucine-rich repeat (LRR) extracellular domain, a transmembrane domain, a juxtamembrane domain, and a cytoplasmic kinase domain (Schultz et al. 1998) (Fig. 3A). The putative extracytoplasmic domains of the four proteins contain five tandem copies of an LRR with 22 to 24 amino acids in each (Table 1) (Jones et al. 1994; Komjanc et al. 1999; Mu et al. 1994; Muschietti et al. 1998; Song et al. 1995). Based on PROSITE analysis (Fig. 3B), all four DIPMs contain 12 characteristic subdomains within their kinase domains, like most eukaryotic protein kinases (Hanks and Hunter 1995; Hofmann et al. 1999). The signature amino acid sequences -HGNLKSSN, found in subdomain VI $b$, and SAGYK/RAPE, in subdomain VIII, are predictive of a serine/threonine protein kinase (Hanks and Hunter 1995).

A highly conserved lysine residue in subdomain II of most protein kinases is involved in ATP binding and is required for kinase activity (Hanks and Hunter 1995). This lysine also is conserved in all four DIPMs. When the lysine residue in kinase

\begin{tabular}{|c|c|c|c|c|c|c|c|c|}
\hline \multirow[t]{2}{*}{$\begin{array}{r}\text { A DIPM1 } \\
\text { DIPM2 } \\
\text { DIPM3 } \\
\text { DIPM4 }\end{array}$} & $\begin{array}{ll}1 & 21 \\
1 & 24 \\
1 & 22 \\
1 & 22 \\
\end{array}$ & & $\begin{array}{l}283 \\
285 \\
287 \\
279 \\
\end{array}$ & $\begin{array}{l}306 \\
307 \\
309 \\
301 \\
\end{array}$ & $\begin{array}{l}363 \\
322 \\
340 \\
327 \\
\end{array}$ & $\begin{array}{l}391 \\
364 \\
378 \\
372 \\
\end{array}$ & & $\begin{array}{l}647 \\
642 \\
646 \\
649 \\
\end{array}$ \\
\hline & SP & $\begin{array}{l}\text { EXTRACELLULAR } \\
\text { LRR(5) }\end{array}$ & & TM & $\begin{array}{l}14 \\
J M\end{array}$ & & KINASE & \\
\hline
\end{tabular}

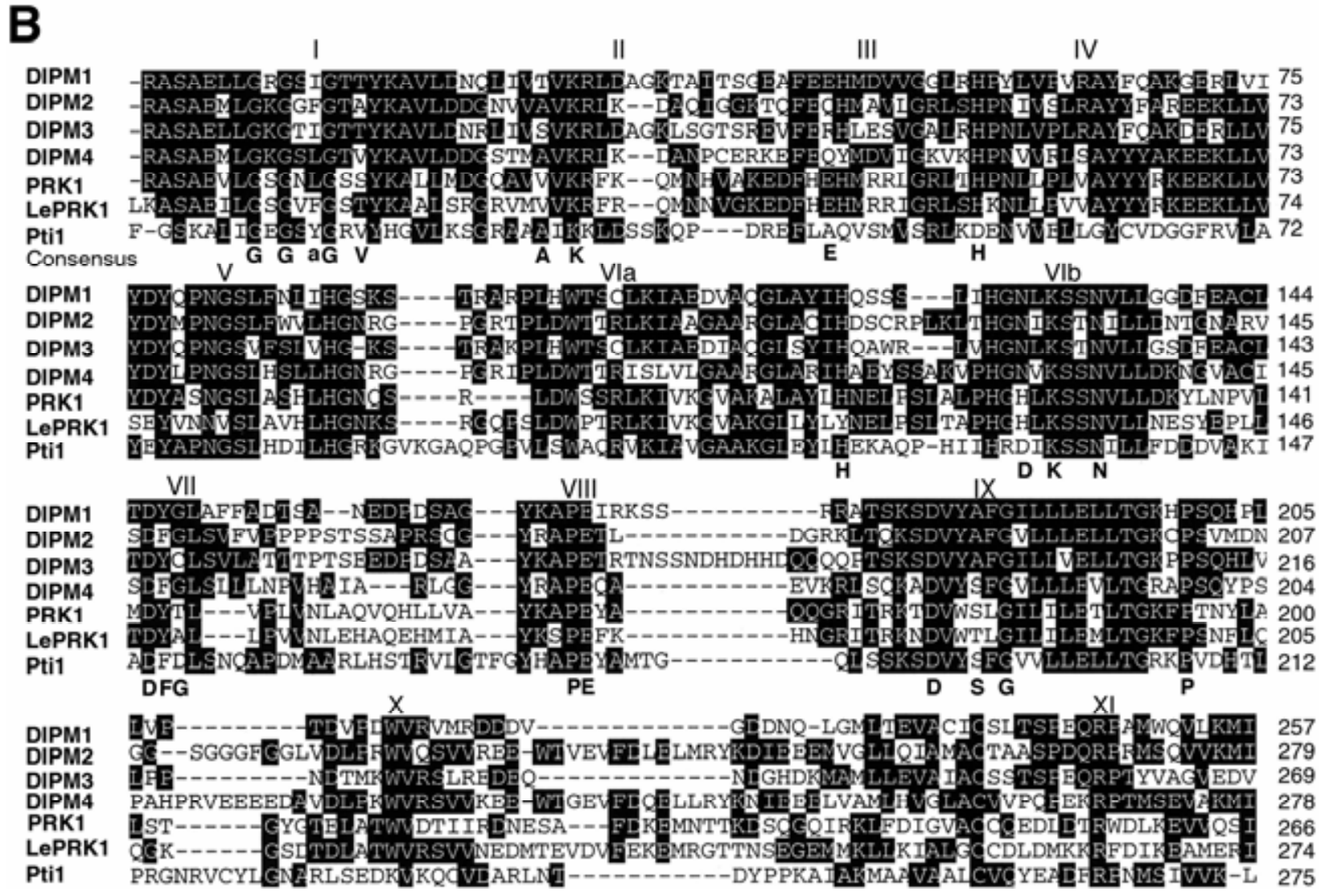

Fig. 3. Structural features and alignment of the kinase domain of four DspA/E-interacting proteins of Malus spp. (DIPMs) with other selected kinases. A, Structural features of the four polypeptides. Numbers above the diagram indicate the amino acid position from the N-terminus. The domains of the four polypeptides are indicated. SP, signal peptide; TM, transmembrane domain; JM, juxtamembrane domain. Arrows indicate the region that was initially identified as interacting with DspA/E' in the yeast two-hybrid screen. B, Alignment of the kinase domain among DIPM1, DIPM2, DIPM3, DIPM4, PRK1 of petunia (Mu et al. 1994), LePRK1 (Muschietti et al. 1998), and Pti1 of tomato (Zhou et al. 1995). The 12 conserved protein kinase subdomains are indicated from I to XI and the invariant or highly conserved amino acids in these domains (Hanks and Hunter 1995) are shown in bold capital letters (consensus). 
Table 1. Comparison of the leucine-rich repeat (LRR) consensus sequence of DspA/E-interacting proteins of Malus spp. (DIPMs) and other LRR proteins

\begin{tabular}{llc}
\hline Protein & \multicolumn{1}{c}{ LRR consensus sequence $^{\text {a }}$} & No. of repeats \\
\hline DIPM1 & LxxLxxLxLxxNxLSGPaPxxL & 5 \\
DIPM2 & LxxLxxLxLxxNxLSGxIPxxa & 5 \\
DIPM3 & LxxLxxLxLxxNxLTGxaPxx & 5 \\
DIPM4 & LxxLxxLxLxNNxLxGxVPxx & 5 \\
PRK1 & LxxLxxaxxLxLxNNxxxGI & 5 \\
LePRK1 & LxxaxaxNNxaxGxIP & 6 \\
LRPKm1 & AxxaxxLxxaxLxxNxaxGxaPxx & 23 \\
Xa21 & LxxaxLxxNxaxGxIP & 23 \\
Cf-9 & LxxLxLSxNxaxGxIPxx & 29 \\
\hline
\end{tabular}

a An " $x$ " represents any amino acid, and an "a" represents an aliphatic amino acid (L, I, F, V, M). The LRR consensus of DIPMs are compared with other LRR-containing proteins, including PRK1 (Mu et al. 1994), LePRK1 (Muschietti et al. 1998), LRPKm1 (Komjanc et al. 1999), Xa21 (Song et al. 1995), and Cf-9 (Jones et al. 1994). subdomain II was replaced with an asparagine residue by sitedirected mutagenesis, the interaction of mutants with DspA/ $\mathrm{E}^{\prime}$ was reduced based on yeast two-hybrid assays (Fig. 1C). In the case of DIPM3, the interaction was abolished. Quantitative assay of $\beta$-galactosidase activity of yeast transformants of the four mutants and $\mathrm{DspA} / \mathrm{E}^{\prime}$ confirmed the same conclusions (data not shown). These results suggest that the ATP-binding motif may be involved in the interaction between DIPMs and DspA/E'.

Amino acid sequence alignment of the four DIPMs demonstrated that they have a high degree of identity in their LRR and kinase domains, but that their overall amino acid homology is relatively low (Fig. 3B). The two most similar clones (DIPM1 and DIPM3) have 56\% identity in DNA sequence, and $53 \%$ identity and $67 \%$ similarity in protein sequence (Fig. 3B). The four proteins exhibit very similar domain patterns
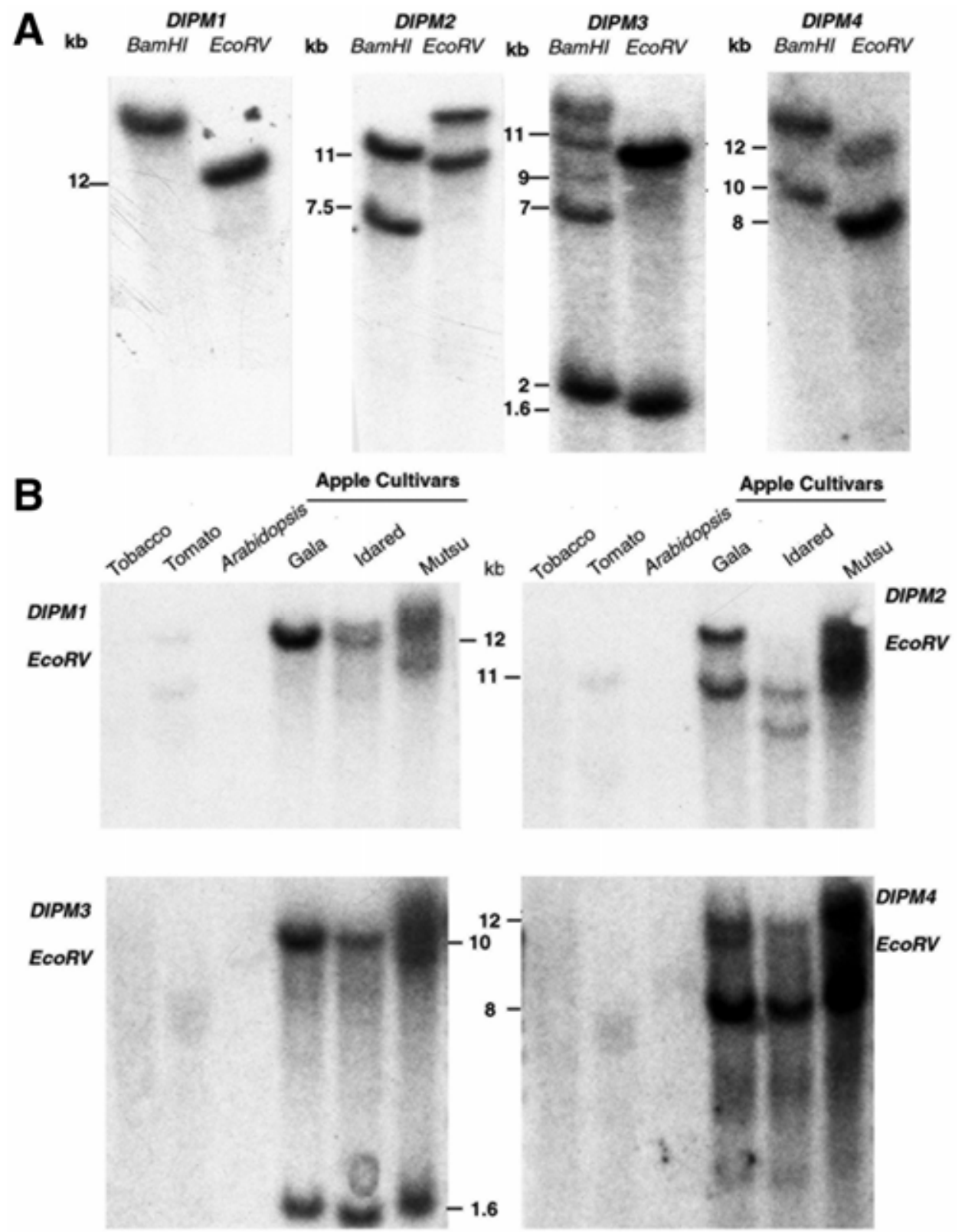

Fig. 4. Southern blot of genomic DNAs with the four probes from apple. A, Southern blot of apple (cv. Gala) genomic DNA digested with BamHI or EcoRV and probed with the four DspA/E-interacting protein of Malus spp. (DIPM) cDNAs. B, Low stringency Southern hybridization of genomic DNA from different plants, including the nonhost plants tobacco, tomato, and Arabidopsis (Col.), and the host plants (apple cvs. Gala, Idared, and Mutsu). The presence of the four genes also was confirmed in host plants by Southern hybridization of genomic DNA of pear, hawthorn, cotoneaster, pyracantha, plum, and strawberry. The four genes were not detected in genomic DNA of the nonhost plants soybean, green bean, willow, and poplar (these genomic DNAs were blotted in separate membranes). 
and they may have similar functions in interacting with the DspA/E effector. The partial cDNA clones isolated from the yeast two-hybrid screen included only the C-terminal approximately 400 amino acids containing the kinase domain of the DIPMs; therefore, it is likely that the intracellular kinase domain is required for interaction with DspA/E. This also was confirmed by results of a yeast two-hybrid assay, in which the DIPM LRR domains did not interact with DspA/E' (data not shown).

\section{Homologs of DIPM genes from other plants.}

An in silico search using the translated sequences from each of the four DIPMs revealed four putative LRR transmembrane protein kinases from Arabidopsis with between 58 and 69\% identity to the respective DIPMs (data not shown). In addition, a BLAST search of GenBank revealed that DIPMs shared high identity to a family of plant proteins collectively called serine/ threonine receptor-like protein kinase (RLK), such as PRK1 of Petunia inflata (Mu et al. 1994) and LePRK1 of Lycopersicon esculentum (Muschietti et al. 1998). The kinase domain of DIPM1 shares 42,41 , and $37 \%$ sequence identity with the kinase domains of PRK1 (Mu et al. 1994), LePRK1 (Muschietti et al. 1998), and Ptil (Zhou et al. 1995), respectively (Fig. 3B).

\section{DIPM genes are conserved and constitutively expressed in host plants.}

Southern blot analysis of genomic DNA from host plants showed that DIPM1 is a unique single-copy gene in apple, whereas DIPM2, DIPM3, and DIPM4 are present in one or more copies in the apple genome (Fig. 4A). The presence of the four genes was confirmed by Southern blotting of genomic DNA in pear, hawthorn, cotoneaster, pyracantha, plum, and strawberry, all of which are hosts for E. amylovora (data not shown). The same probes failed to hybridize even at low stringency to genomic DNA from nonhost plants, including tomato, tobacco, Arabidopsis, soybean, green bean, willow, and poplar (Fig. 4B) (the last four plant genomic DNAs were blotted onto a separate membrane). Northern blot analysis of total RNA from young shoots of several apple cultivars that differ in susceptibility or resistance to E. amylovora showed that the four genes are expressed in young shoots (Fig. 5). Inoculation of

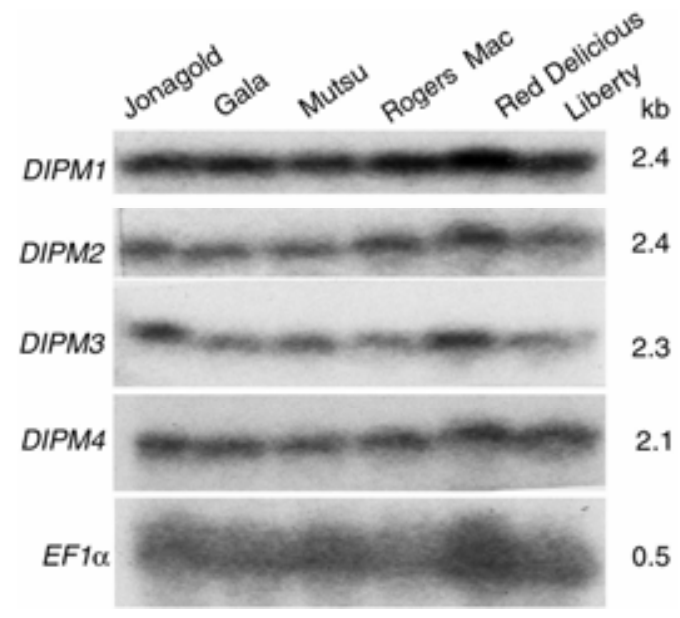

Fig. 5. Expression of the identified genes in young apple shoots. The four transcripts of the DIPMs were expressed in the apple cvs. Jonagold, Gala, Mutsu, Rogers Mac, Red Delicious, and Liberty. Apple shoot tips were harvested from a commercial orchard in spring. Total RNA was isolated according to the method of Komjanc and associates (1999). After transfer to nylon membranes, the RNA was detected by probing with ${ }^{32} \mathrm{P}$-labeled DIPM fragments. apple trees with E. amylovora did not enhance expression of $D I P M 1$ in young shoots. On the contrary, DIPM1 transcripts were not detected by northern blot analysis $96 \mathrm{~h}$ postinoculation (Fig. 6).

\section{DISCUSSION}

The yeast two-hybrid system was used to identify apple proteins that specifically interact with DspA/E, a known pathogenicity effector of E. amylovora. Four interacting proteins were identified and named DIPM1 to 4 . The proteins have similar sequence structure and resemble LRR RLKs from other organisms. Based on their deduced amino acid sequences, each has a signal peptide followed by an LRR domain, a transmembrane domain, a juxtamembrane, and a serine/threonine kinase domain. Interactions between DspA/E and the identified apple proteins in the yeast two-hybrid system were confirmed by in vitro pull-down assays.

Protein kinases constitute a major class of signal transducers that mediate responses to a variety of signals, including pathogen invasion, light, hormones, and environmental stress (Torii 2000). An RLK family that contains extracytoplasmic LRR domains has been found to regulate defense responses, developmental processes, and phytohormone perception (GómezGómez et al. 2001; Gómez-Gómez and Boller 2000; Song et al. 1995; Torii 2000). The predicted structure of DIPM is similar to this class of plant $R$ gene products, including Xa21 from rice, which confers resistance to Xanthomonas oryzae (Song et

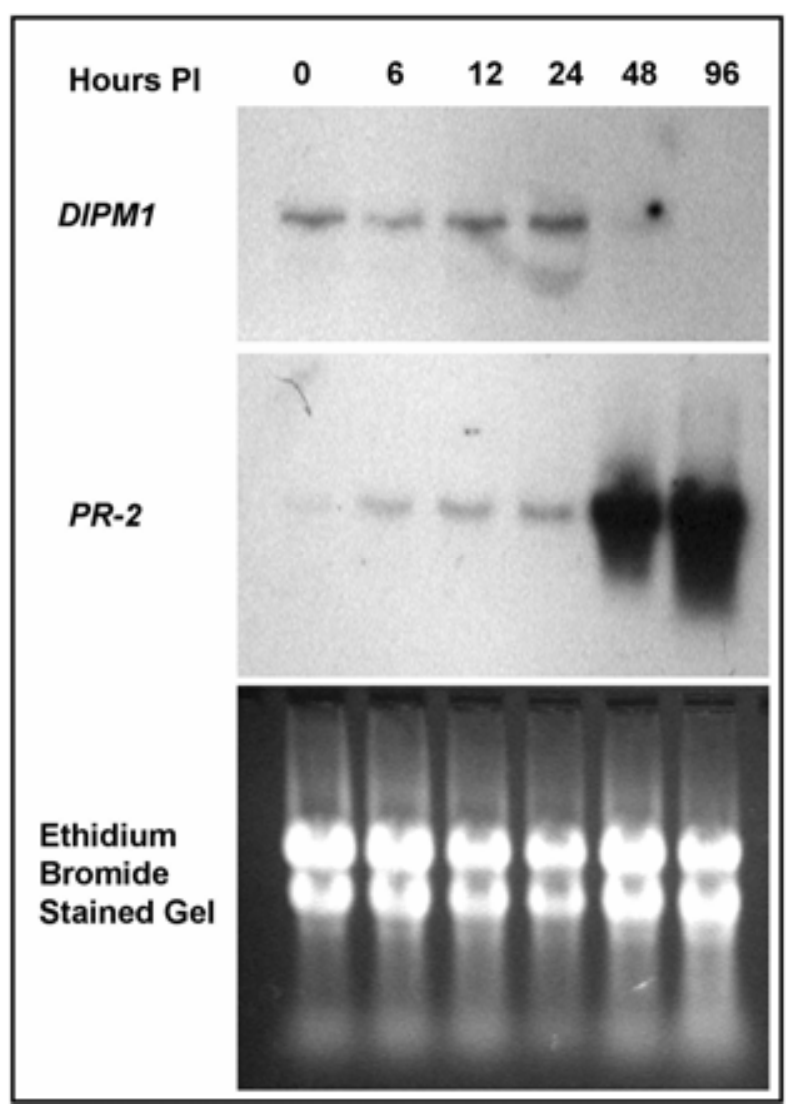

Fig. 6. Expression level of DIPMI and $P R-2$ in apple (cv. Gala) shoots following inoculation with Erwinia amylovora Ea273. Northern blot of RNA from apple shoots harvested prior to inoculation (0), and at 6, 12, 24, 48, and $96 \mathrm{~h}$ postinoculation. A florist's frog, previously dipped in a suspension of strain Ea273, was used for inoculation. Total RNA $(15 \mu \mathrm{g})$ was loaded in each lane. Blots were probed with a 400-bp fragment of DIPMI or a 515-bp fragment of $P R-2$ (GenBank accession no. AY548364), each labeled with digoxigenin. 
al. 1995), and FLS2, which is involved in the perception of the bacterial elicitor flagellin in Arabidopsis (Gómez-Gómez and Boller 2000). Both the extracellular LRR and kinase domains are required for the effector-receptor interaction and signaling in host plants (Ellis et al. 2000; Gomez-Gomez et al. 2001; He et al. 2000).

In our yeast two-hybrid interaction assays, DspA/E interacted only with the intracellular kinase domains of the DIPMs and not with the extracellular domains that contain LRRs. This result is expected based on evidence that DspA/E is translocated to the plant cytoplasm (Bocsanczy et al. 2005) and that the portions of the DIPM molecules that interact with DspA/E are in the same location, thus facilitating their interaction. LRRs are thought to form versatile binding domains that fulfill the receptor role of kinases and often are involved in proteinprotein interaction (Gomez-Gomez et al. 2001; He et al. 2000; Kobe and Deisenhofer 1995). Thus, the overall structures of DIPM1 to 4 indicate that they might function in signal transduction in the E. amylovora-apple combination, perhaps by sensing extracellular signals with LRRs and interacting with effectors through the kinase domains. The identity of those signals and the pathway involved remain to be determined.

Mutation of an invariant lysine in subdomain II reduced the interaction strength between the four apple proteins and $\mathrm{DspA} / \mathrm{E}$ in the yeast two-hybrid assay. This lysine lies within $\beta$-strand 3 of the small lobe and helps to anchor and orient ATP by interacting with the $\alpha$ - and $\beta$-phosphates (Hanks and Hunter 1995). This suggests that mutation of subdomain II may affect the overall structure of the kinases and interfere with their interactions with DspA/E.

The type III-secreted virulence effector of Yersinia pestis, YopJ, is injected into target cells. It binds directly to mitogenactivated protein kinase kinases of its mammalian host, blocking multiple signaling pathways, including the MAPK and NFKB pathways in infected cells (Orth 2002; Orth et al. 1999, 2000). This inhibits activation of the host immune response and induces apoptosis (Navarro et al. 2005; Orth 2002; Orth et al. 1999, 2000). Similarly, DspA/E is a type III effector protein from $E$. amylovora which interacts specifically with the intercellular kinase domain of an RLK from its host, apple. One possible consequence of this interaction may be to block signal transduction leading to a defense response that results in disease development. Further research is needed to test this possibility.

The data presented here demonstrate that four DIPMs from apple, which are putative RLKs, interact with DspA/E, the important pathogenicity effector from E. amylovora. Evidence also was found for the presence of the genes encoding homologs of the DIPMs in all host plants tested. Among the cultivars of apple tested, Gala, Idared, and Jonagold are considered susceptible, whereas Mutsu and Rogers Mac are moderately resistant and Liberty and Red Delicious are most resistant to fire blight (van der Zwet and Beer 1999). Thus, regardless of their relative susceptibility to E. amylovora, DIPMs were expressed in all host plants. The DIPMs may be regarded as targets of the effector protein DspA/E and perhaps susceptibility factors. These new findings demonstrate that "gene-for-gene" resistance might not pertain simply to the interaction between Avr effectors and $R$ gene products. Additional components from hosts are needed to complete the interaction and recognition between the host and pathogen (Chang et al. 2004). Thus, the "guard model" for gene-for-gene resistance, which postulates that Avr effectors interact with specific host proteins (pathogenicity targets) to promote disease and that $\mathrm{R}$ proteins "guard" the pathogenicity target (Dangl and Jones 2001; van der Biezen and Jones 1998), might be relevant to the E. amylovora-apple pathosystem.

We could not detect significant signals of the DIPMs in a Southern blot of soybean genomic DNA probed under low stringency conditions. Blast of expressed sequence tag (EST) databases found that the most similar soybean EST has a $74 \%$ identity with DIPM4 in approximately $600 \mathrm{bp}$ of the kinaseencoding region of the 930-bp fragment probe from DIPM4 (the total identity of the soybean EST to the probe is only approximately 47\%). Nevertheless, DspA/E may act as an Avr protein in soybean when expressed in $P$. syringae pv. glycinea (Bogdanove et al. 1998b). Soybean may have an $R$ gene that encodes a protein that recognizes $\mathrm{DspA} / \mathrm{E}$ and leads to a typical interaction between the $R$ gene and $a v r$ gene products (Chang et al. 2004; Ellis et al. 2000; Gomez-Gomez et al. 2001; He et al. 2000). The interaction between DspA/E and DIPMs likely occurs in the cytoplasm and the LRR domain of the DIPMs do not interact with DspA/E.

The four putative serine-threonine kinases from apple have similar protein structures. They all exist in host plants as isoforms of proteins and they all may be targets of the DspA/E effector of $E$. amylovora. $R$-gene-mediated resistance to fire blight is not known in host plants (Norelli et al. 1984). Because fire blight is indigenous to North America, the disease probably occurred on native plants like crab apple, hawthorn, and mountain ash. The disease was first noticed in the late 18th century near New York City on European-type pear and apple, which had been introduced by the early settlers (Bonn and van der Zwet 2000). During co-evolution of host and pathogen, $E$. amylovora quite likely was favored by the slow evolution of corresponding $R$ genes in its slowly reproducing and generally asexually propagated woody hosts (Clay and Kover 1996).

When E. amylovora infects its host apple and the pathogenicity effector DspA/E is translocated into host cells, it likely interacts with its target DIPMs. The resulting effector-target complex is unlikely to trigger a defense-related pathway leading to resistance because there is no corresponding $R$ gene to sense the complex. On the contrary, the interaction of DspA/E with the DIPMs may suppress a defense response by blocking DIPM signal transduction. In essence, it appears that the DIPMs may act as susceptibility factors that determine, at least in part, whether the plant in question becomes infected by E. amylovora. Northern blot results showed that the four kinases are constitutively expressed in both young shoots and blossoms (blossom data not shown), and their expression was not enhanced by inoculation of trees with $E$. amylovora. In fact, no significant hybridization to DIPMI transcripts was detected by northern blot analysis using $15 \mu \mathrm{g}$ of total RNA harvested from shoots $96 \mathrm{~h}$ postinoculation. However, the necrotic condition of the inoculated tissue at both 48 and $96 \mathrm{~h}$ postinoculation may have precluded isolation of nonabundant transcripts. These results suggest that DIPMs may be specific targets, which are constitutively expressed in apple and interact with DspA/E, the well-known pathogenicity effector of E. amylovora.

Our data have established that direct protein-protein interaction occurs between a type III-secreted pathogenicity effector, DspA/E, and four specific host proteins. Loss of function and gain of function mutational analyses currently are underway. The results from these experiments should clarify the role of the interaction between DspA/E from E. amylovora and DIPMs from Malus $\times$ domestica in the development of fire blight.

\section{MATERIALS AND METHODS}

\section{Yeast two-hybrid system.}

The Matchmaker LexA two-hybrid system (Clontech, Palo Alto, CA, U.S.A.) was used as described by the manufacturer. The complete coding region and a 2.9-kb fragment of the $5^{\prime}$ end of the coding region of $d s p A / E$ were amplified by PCR using an Xhol-tagged upstream primer (5'-GCGCTCGAGTCA TGGAATTAAAAT-CACTG-3') and the downstream primer 
(5'-CGCCTCGAGATTAGCTC TTCATTTCCAGC-3' or 5'CTG CTCGAGCATAGGCGCGG ATCCTTTCG-3'), respecttively. The amplicons were digested with $\mathrm{XhoI}$ and cloned into the SalI site of the pGilda bait plasmid. The resulting plasmids were named pGilda-5.5dspA/E and pGilda-2.9dspA/E. Orientation and in-frame fusion of sequences in the constructs were confirmed by sequencing. The constructs were transformed into the yeast strain EGY48 containing either pJK101 to confirm that the LexA-DspA/E fusion protein is translocated into the nucleus or the reporter plasmid p8op-lac $Z$ to test for possible activation of the reporter genes by the LexA-DspA/E fusion constructs (Golemis et al. 1997). The LexA-DspA/E' fusion protein was confirmed to be expressed in yeast under inducing conditions by western blot analysis using LexA antibody (Clontech, data not shown). Total RNA was extracted from young apple shoots (Malus $\times$ domestica $\mathrm{cv}$. Gala) by a phenol/ chloroform method (Komjanc et al. 1999). PolyA RNA was isolated by polyATtract mRNA Isolation System (Promega Corp., Madison, WI, U.S.A.). cDNA was synthesized (Snead et al. 1997), cloned into prey vector pB42AD, and transformed into XL10-gold competent cells (Stratagene, La Jolla, CA, U.S.A.) by electroporation. More than $2 \times 10^{6}$ colonies containing the primary cDNAs were obtained. The cDNA inserts were confirmed by miniprep and analytical restriction enzyme digestion. The plasmid DNA from the library was transformed en masse into the yeast strain EGY48 containing the LexA-DspA/E' construct and p8op-lacZ, the lac $Z$ reporter plasmid. Approximately $1.4 \times 10^{6}$ transformants grew on glucose plates lacking uracil, histidine, and tryptophan, and $1 \times 10^{8}$ yeast cells were plated on $5015-\mathrm{cm}$ plates containing galactose, raffinose, $\mathrm{X}-\mathrm{Gal}, \mathrm{BU}$ salts medium lacking uracil, histidine, tryptophan, and leucine. The plates were incubated at $30^{\circ} \mathrm{C}$ for 5 days for bait and prey interacttion screening and were checked every $12 \mathrm{~h}$ for blue colonies, which were collected for further screening. The blue colonies were restreaked and screened on four types of media for confirmation of induced interactions (Golemis et al. 1997). PCR screening and restreaking screening procedures were used to select yeast colonies for isolation of $\mathrm{pB} 42 \mathrm{AD}$ plasmids containing cDNA inserts (Golemis et al. 1997). cDNA candidates also were retransformed into yeast containing bait and reporter genes, or only reporter genes, to confirm the interaction and the absence of self-activation. The interacting cDNA clones were confirmed by expression as HA fusion protein in yeast under inducing conditions using HA antibody (Clontech).

\section{Southern blot.}

Genomic DNA was isolated from young shoots or leaves of various plants with the method of Dellaporta and associates (1983). Approximately $10 \mu \mathrm{g}$ of genomic DNA was digested with BamHI or $E c o \mathrm{RV}$ and resolved on a $0.7 \%(\mathrm{wt} / \mathrm{vol})$ agarose gel. The DNA was transferred to Nytran SuPercharge membranes (Schleicher \& Schuell, Keene, NH, U.S.A.), prehybridized for $2.5 \mathrm{~h}$ at $65^{\circ} \mathrm{C}$ with buffer as described by Scutt (1997), and then hybridized with one of the four cDNA probes overnight at $65^{\circ} \mathrm{C}$. The four probe templates were fragments of cDNA from the identified interacting prey clones (digested with EcoRI and XhoI, which produced fragments of 960, 760, 1,100 , and $930 \mathrm{bp}$ in length, respectively). Probes were synthesized using the Prime-it II labeling kit (Stratagene). The membranes were washed at high stringency with $2 \times$ SSC $(1 \times$ SSC is $0.15 \mathrm{M} \mathrm{NaCl}$ plus $0.015 \mathrm{M}$ sodium citrate), $0.1 \%$ (wt/vol) SDS at $65^{\circ} \mathrm{C}$ for $3 \times 20 \mathrm{~min}$ and then with $0.1 \times \mathrm{SSC}, 0.1 \%$ (wt/vol) SDS at $65^{\circ} \mathrm{C}$ for $10 \mathrm{~min}$. Low-stringency washes were done in $2 \times \mathrm{SSC}, 0.1 \%(\mathrm{wt} / \mathrm{vol}) \mathrm{SDS}$ at room temperature for $2 \times 30 \mathrm{~min}$ and once for $60 \mathrm{~min}$ at $50^{\circ} \mathrm{C}$.

\section{Plant inoculation.}

For plant inoculation, 1-year-old apple trees growing in containers were pruned to two shoots and maintained in a greenhouse until shoot lengths reached 20 to $30 \mathrm{~cm}$. Inoculations were performed in a controlled environment chamber in which the temperature was maintained at $26^{\circ} \mathrm{C}$ with a minimum relative humidity of $65 \%$ and a 12-h light period of fluorescent and incandescent lighting. For inoculation, vigorously growing vegetative shoots were pricked with multiple pins of a florist's frog that had been dipped immediately previously in a suspension of E. amylovora. The top 2 to $4 \mathrm{~cm}$ of each shoot tip was placed between the pins of the device and a gloved hand, which supplied sufficient force to prick the shoot tissues. The hand was covered with a Purple-Nitrile glove (Kimberly-Clark, Roswell, GA, U.S.A.). Inoculum consisted of strain Ea273 at $10^{8}$ cells $/ \mathrm{ml}$ in $5 \mathrm{mM}$ phosphate buffer, $\mathrm{pH} 6.5$. The inoculated trees were held in the chamber under the conditions described above during disease development. The inoculated trees were examined at least daily for 6 days for symptom development.

\section{Gene expression studies.}

To determine the levels of expression of the DIPMs in several apple cultivars, shoots and blossoms were collected from apple trees growing in a commercial orchard. Total RNA was extracted according to the methods of Komjanc and associates (1999). Approximately $10 \mu \mathrm{g}$ of total RNA from each tissue sample was resolved on $1.2 \%$ (wt/vol) formaldehyde agarose gels and then transferred to Magna nylon membranes (Osmonic, Minnetonka, MN, U.S.A.). RNA on the membranes was hybridized to the same probes as used for the Southern blots (described above) in ULTRAhybe buffer (Ambion, Austin, TX, U.S.A.) for $18 \mathrm{~h}$ at $42^{\circ} \mathrm{C}$. The membranes then were washed for $2 \times 5 \mathrm{~min}$ in $2 \times \mathrm{SSC}, 0.1 \%$ (wt $/ \mathrm{vol}$ ) SDS and for $2 \times 15 \mathrm{~min}$ in $0.1 \times \mathrm{SSC}, 0.1 \%(\mathrm{wt} / \mathrm{vol}) \mathrm{SDS}$, also at $42^{\circ} \mathrm{C}$. EF1 $\alpha$ was assayed as a control for RNA loading according to the same procedures used for the assay of the other genes.

For expression in response to inoculation with E. amylovora, $15 \mu \mathrm{g}$ of total RNA from each tissue sample, isolated according to the methods of Komjanc and associates (1999), was resolved on $1.2 \%(\mathrm{wt} / \mathrm{vol})$ formaldehyde agarose gels and transferred to Magna nylon membranes (Osmonic). RNA on the membranes was hybridized to a 400-bp fragment located between the transmembrane domain and the kinase domain of $D I P M 1$ or a 515-bp fragment of $P R-2$ (GenBank accession AY548364) labeled using the PCR DIG Probe Synthesis Kit (Roche Molecular Biochemicals, Indianapolis, IN, U.S.A.). Detection was carried out as directed by the manufacturer using the chemiluminescent substrate, "CSPD, ready-to-use" (Roche Molecular Biochemicals).

\section{5' RACE for isolation of full-length cDNA.}

The FirstChoice RLM-RACE kit (Ambion) was used following the manufacturer's $5^{\prime}$ RACE procedures to obtain the $5^{\prime}$ end cDNAs from total RNA (isolated as previously described) using gene-specific primers designed from upstream sequences of cDNA inserts from the four selected clones.

\section{Bioinformatics.}

Plasmids containing interacting cDNA inserts were sequenced on an ABI 3700 DNA Sequencer at the Cornell University Biotechnology Resource Center Sequencing Facility. DNA sequence data were analyzed using Lasergene from DNASTAR (Madison, WI, U.S.A.) and the deduced amino acid sequences were compared with sequences in the current databases (GenBank, Swiss Protein, and EMBL) by using the BLAST on the National Center for Biotechnology Information web site, SMART, and Prosite (Hofmann et al. 1999). 
In vitro mutagenesis

of putative kinase domains and interaction assay

of kinase and extracellular domains with DspA/E'.

QuikChange site-directed mutagenesis kit (Stratagene) was used to make a lysine to asparagine substitution at subdomain II of the four kinases in pB42AD. The four sets of primers used were DIPM1, 5'-GATTGTGACGGTGAACAG ATTGGACGCC GGC $3^{\prime}$ and 5'-GCCGGCGTCCAATCTGT TCACCGTCACAATC 3'; DIPM2, 5'-GTGG TGGCGGTTA ACAGGCTCAAGGATGC $3^{\prime}$ and 5'-GCATCCTTGAGCCT GTTAACCGCC ACCAC 3'; DIPM3, (5'-GATCGTGAGCG TGAACAGGCTCGATGCCGGG $3^{\prime}$ and $5^{\prime}$-CCCGGCATCG AGCCTGTTCACGCTCACGATC 3'; and DIPM4, 5'-CACA ATGGCGGT GAACCGGCTCAAGGACGCG $3^{\prime}$ and $5^{\prime}-\mathrm{CG}$ CGTCCTTGAGCCGGTTCACCGCCATT GTG 3'. The resulting mutations were confirmed by sequencing, and expression of mutant protein in yeast was confirmed by western blot analysis. The mutants were tested for interaction with DspA/E' in the yeast two-hybrid system as described above. FluroAce $\beta$-galactosidase reporter assay kit (Bio-Rad, Hercules, CA, U.S.A.) was used to quantitatively assay $\beta$-galactosidase activity of yeast transformants with different baits and preys. At least six colonies were used for detecting each transformant. The extracellular domains that contain the LRR from the DIPMs were cloned in pB42AD and tested for interaction with DspA/E2.9N-terminal in pGlida in the yeast twohybrid assay. Expression of the extracellular LRR domains was confirmed by western blot analysis using HA antibody.

\section{T7•Tag fusion protein expression and in vitro pull-down assay.}

The cDNA inserts in pB42AD encoding the interacting kinase domains were amplified by PCR and ligated with the pET24a expression vector containing T7•Tag (Novagen, Madison, WI, U.S.A.). The T7•Tag fusion proteins were expressed in Escherichia coli B21-Gold-DE3 (Stratagene) and cell lysates were purified by $\mathrm{T} 7 \bullet$ Tag antibody agarose from Novagen. Cell lysates from the four kinase clones containing approximately $5 \mu \mathrm{g}$ of fusion proteins and from a control strain with the empty vector were incubated with $50 \mu \mathrm{l}$ of $\mathrm{T} 7 \bullet$ Tag antibody agarose beads at $4^{\circ} \mathrm{C}$ for $1 \mathrm{~h}$ with rotation. Beads then were washed three times with washing/binding buffer (Novagen). The washed beads were incubated with an equal volume of cell lysate $(200 \mu \mathrm{l})$ of Escherichia coli DH5 $\alpha$ expressing the N-terminal half of DspA/E (DspA/E') or DspA/E (Bogdanove et al. 1998a,b) at $4^{\circ} \mathrm{C}$ for $1 \mathrm{~h}$ with rotation. The beads were washed four times with washing/ binding buffer and resuspended in $50 \mu \mathrm{l}$ of washing buffer; $30 \mu \mathrm{l}$ of bead suspension was mixed with loading buffer and held in boiling water for $5 \mathrm{~min}$, after which the proteins were resolved on a $10 \%$ (wt/vol) SDS-PAGE gel. Proteins were transferred to polyvinylidene diflouride membrane (Millipore, Bedford, MA, U.S.A.) by semi-dry trans-blot (Bio-Rad). $\mathrm{DspA} / \mathrm{E}$ protein was detected with antibody to $\mathrm{DspA} / \mathrm{E}$ (Bogdanove et al. 1998b), and the Western-Star immunodetection system (Tropix, Bedford, MA, U.S.A.) was used to detect binding of DspA/E protein with T7-Tag-fused identified apple proteins. The T7•Tag antibody (Novagen) was used to detect $\mathrm{T} 7 \bullet$ Tag-fused identified apple proteins.

\section{ACKNOWLEDGMENTS}

This work was supported in part by United States Department of Agriculture Special Grant 2001-203085 and others. We thank G. B. Martin for supplying the bait vectors, useful discussion, and critical reading of the work; P. Ronald for Xa21 clones; W.-S. Kim for some of the in vitro protein expression work; and T. P. Delaney for helpful discussion.

\section{LITERATURE CITED}

Abramovitch, R. B., and Martin, G. B. 2004. Strategies used by bacterial pathogen to suppress plant defenses. Curr. Opin. Plant Biol. 7:356-364.

Bocsanczy, A. M., Nissinen, R. M., Oh, C.-S., and Beer, S. V. DspE, an effector of Erwinia amylovora is translocated into plant cells. Acta. Hortic. In press.

Bogdanove, A. J., Bauer, D. W., and Beer, S. V. 1998a. Erwinia amylovora secretes DspE, a pathogenicity factor and functional AvrE homolog, through the Hrp (type III secretion) pathway. J. Bacteriol. 180:2244-2247.

Bogdanove, A. J., Kim, J. F., Wei, Z., Kolchinsky, P., Charkowski, A. O. Conlin, A. K., Collmer, A, and Beer, S. V. 1998b. Homology and functional similarity of an $h r p$-linked pathogenicity locus, $d s p E F$, of $E r$ winia amylovora and the avirulence locus avrE of Pseudomonas syringae pathovar tomato. Proc. Natl. Acad. Sci. U.S.A. 95:1325-1330.

Bonn, W. G., and van der Zwet, T. 2000. Distribution and economic importance of fire blight. Pages 37-54 in: Fire Blight, the Disease and Its Causative Agent, Erwinia amylovora. J. L. Vanneste, ed. CAB International, Wallingford, U.K.

Chang, J. H., Goel, A. K., Grant, S. R., and Dangl, J. F. 2004. Wake of the flood: ascribing functions to the wave of type III effector proteins of phytopathogenic bacteria. Curr. Opin. Micribiol. 7:11-18.

Chen, Z., Kloek, A. P., Boch, J., Katagiri, F., and Kunkel, B. N. 2000. The Pseudomonas syringae avrRpt2 gene product promotes pathogen virulence from inside plant cell. Mol. Plant-Microbe Interact. 12:1312-1321.

Chen, Z., Kloek, A. P., Cuzick, A., Moeder, W., Tang, D., Innes, R. W., Klessig, D. F., McDowell, J. M., and Kunkel, B. N. 2004. The Pseudomonas syringae type III effector AvrRpt2 functions downstream or independently of SA to promote virulence on Arabidopsis thaliana. Plant J. 37:494-504.

Chisholm, S. T., Dahlbeck, D., Krishnamurthy, N., Day, B., Sjolander, K., and Staskawicz, B. J. 2005. Molecular characterization of proteolytic cleavage sites of Pseudomonas syringae effector AvrRpt2. Proc. Natl. Acad. Sci. U.S.A. 102:2087-2092.

Clay, A., and Kover, P. X. 1996. The red queen hypothesis and plant/pathogen interaction. Annu. Rev. Phytopathol. 34:29-50.

Dangl, J. L., and Jones, J. D. G. 2001. Plant pathogens and integrated defense responses to infection. Nature 411:826-833.

Dellaporta, S. L., Wood, J., and Hicks, J. B. 1983. A plant DNA minipreparation: version 2. Plant Mol. Biol. Rep. 1:19-22.

Deslandes, L., Olivier, J., Peeters, N., Feng, D. X., Khounlotham, M., Boucher, C., Somssich, I., Genin, S., and Marco, Y. 2003. Physical interaction between RRS-1R, a protein conferring resistance to bacterial wilt, and PopP2, a type III effector targeted to the plant nucleus. Proc. Natl. Acad. Sci. U.S.A. 100:8024-8029.

Ellis, J., Dodds, P., and Pryor, T. 2000. Structure, function and evolution of plant defense genes. Curr. Opin. Plant Biol. 3:278-284.

Galán, J. E., and Collmer, A. 1999. Type III secretion machines: bacterial devices for protein delivery into host cells. Science 284:1322-1328.

Gaudriault, S., Malandrin, L., Paulin, J.-P., and Barny, M.-A. 1997. DspA, an essential pathogenicity factor of Erwinia amylovora showing homology with AvrE of Pseudomonas syringae, is secreted via the Hrp secretion pathway in a DspB-dependent way. Mol. Microbiol. 26:1057-1069.

Golemis, E. A., Serebriiskii, I., Gyuris, J., and Brent, R. 1997. Interaction trap/two-hybrid system to identify interacting proteins. Pages 20.1120.35 in Curr. Protocols in Mol. Biol. F. M. Ausubel, R. Brent, R. E. Kinston, D. D Moore, J. G. Seidman, J. A, Smith, and K. Struhl, eds. John Wiley \& Sons, New York.

Gomez-Gomez, L., Bauer, Z., and Boller, T. 2001. Both the extracellular leucine-rich repeat domain and the kinase activity of FLS2 are required for flagellin binding and signaling in Arabidopsis. Plant Cell 13:11551163.

Gomez-Gomez, L., and Boller, T. 2000. FLS2: An LRR receptor-like kinase involved in the perception of the bacterial elicitor flagellin in Arabidopsis. Mol. Cell 5:1003-1011.

Greenberg, J. T., and Vinatzer, B. A. 2003. Identifying type III effectors of plant pathogens and analyzing their interaction with plant cells. Curr. Opin. Microbiol. 6:20-28.

Gyuris, J., Golemis, E. A., Chertkov, H., and Brent, R. 1993. Cdi1, a human G1- and S-phase protein phosphatase that associates with Cdk2. Cell 75:791-803.

Hanks, S. K., and Hunter, T. 1995. The eukaryotic protein kinase superfamily: kinase (catalytic) domain structure and classification. FASEB J. 9:576-596.

He, Z., Wang, Z.-Y., Li, J., Zhu, Q., Lamb, C., Ronald, P., and Chory, J. 2000. Perception of brassinosteroids by the extracellular domain of the receptor kinase BRI1. Science 288:2360-2363.

Hofmann, K., Bucher, P., Falquet, L., and Bairoch, A. 1999. The PROSITE database, its status in 1999. Nucleic Acids Res. 27:215-219. 
Innes, R. W. 2001. Targeting the targets of type III effector proteins secreted by phytopathogenic bacteria. Mol. Pathol. 2:109-115.

Innes, R. W. 2004. Guarding the goods. New insights into the central alarm system of plants. Plant Physiol. 135:695-701.

Jackson, R. W., Athanassopoulos, E., Tsiamis, G., Mansfield, J. W., Sesma, A., Arnold, D. L., Gibbon, M. J., Murillo, J., Taylor, J. D., and Vivian, A. 1999. Identification of a pathogenicity island, which contains genes for virulence and avirulence, on a large native plasmid in the bean pathogen Pseudomonas syringae pathovar phaseolicola. Proc. Natl. Acad. Sci. U.S.A. 96:10875-10880.

Jia, Y., McAdams, S. A., Bryan, G. T., Hershey, H. P., and Valent, B. 2000. Direct interaction of resistance gene and avirulence gene products confers rice blast resistance. EMBO (Eur. Mol. Biol. Organ.) J. 19:40044014.

Jones, D. A., Thomas, C. M., Hammond-Kosack, K. E., Balintkurti, P. J., and Jones, J. D. G. 1994. Isolation of the tomato $C f-9$ gene for resistance of Cladosporium fulvum by transposon tagging. Science 266:789-793.

Kjemtrup, S., Nimchuk, Z., and Dangl, J. L. 2000. Effector proteins of phytopathogenic bacteria: bifunctional signals in virulence and host recognition. Curr. Opin. Microbiol. 3:73-78.

Kobe, B., and Deisenhofer, J. 1995. A structure basis of the interactions between leucine-rich repeats and protein ligands. Nature 374:183-186.

Komjanc, M., Festi, S., Rizzotti, L., Cattivelli, L., Cervone, F., and De Lorenzo, G. 1999. A leucine-rich repeat receptor-like kinase (LRPKm1) gene is induced in Malus $\times$ domestica by Venturia inaequalis infection and salicylic acid treatment. Plant Mol. Biol. 40:945-957.

Lahaye, T., and Bonas, U. 2001. Molecular secrets of bacterial type III effector proteins. Trends Plant Sci. 6:479-485.

Lorang, J. M., Shen, H., Kobayashi, D., Cooksey, D., and Keen, N. T. 1994. avrA and avrE in Pseudomonas syringae pv. tomato PT23 play a role in virulence on tomato plants. Mol. Plant-Microbe Interact. 7:508-515.

Mackey, D., Belkhadir, Y., Alonos, J. M., Ecker, J. R., and Dangl, J. L. 2003. Arabidopsis RIN4 is a target of the type III virulence effector AvrRpt2 and modulates RPS2-mediated resistance. Cell 112:284-286.

Mackey, D., Holt, B. F., III, Wiig, A., and Dangl, J. L. 2002. RIN4 interacts with Pseudomonas syringae type III effector molecules and is required for RPM1-mediated resistance in Arabidopsis. Cell 108:743-754.

$\mathrm{Mu}$, J.-H., Lee, H.-S., and Kao, T.-H. 1994. Characterization of a pollenexpressed receptor-like kinase gene of Petunia inflata and the activity of its encoded kinase. Plant Cell 6: 709-721.

Muschietti, J., Eyal, Y., and McCormick, S. 1998. Pollen tube localization implies a role in pollen-pistil interactions for the tomato receptor-like kinases LePRK1 and LePRK2. Plant Cell 10:319-330.

Navarro, L., Alto, N. M., and Dixon, J. E. 2005. Functions of the Yersinia effector proteins in inhibiting host immune responses. Curr. Opin. Microbiol. 8:21-27.

Nimchuk, Z., Eulgem, T., Holt, B. F., III, and Dangl, J. L. 2003. Recognition and response in the plant immune system. Annu. Rev. Genet. 37:579-609.

Norelli, J. L., Aldwinckle, H. S., and Beer, S. V. 1984. Differential host $\times$ pathogen interactions among cultivars of apple and strains of Erwinia amylovora. Phytopathology 74:136-139.

Oh, C.-S., Kim, J. F., and Beer, S. V. 2005. The Hrp pathogenicity island of Erwinia amylovora and identification of three novel genes required for systemic infection. Mol. Plant Pathol. 6:125-138.

Orth, K. 2002. Function of the Yersinia effector YopJ. Curr. Opin. Microbiol. 5:38-43.

Orth, K., Palmer, L. E., Bao, Z. Q., Stewart, S., Rudolph, A. E., Bliska, J. B., and Dixon, J. E. 1999. Inhibition of the mitogen-activated protein kinase kinase superfamily by Yersinia effector. Science 285:19201923.
Orth, K., Xu, Z., Mudgett, M. B., Bao, Z. Q., Palmer, L. E., Bliska, J. B. Mangel, W. F., Staskawicz, B. J., and Dixon, J. E. 2000. Disruption of signaling by Yersinia effector YopJ, a ubiquitin-like protein protease. Science 290:1594-1597.

Ritter, C., and Dangl, J. L. 1995. The avrRpm1 gene of Pseudomonas syringae pv. maculicola is required for virulence on Arabidopsis. Mol. Plant-Microbe Interact. 8:444-453.

Salmeron, J. M., Oldroyd, G. E. D., Rommens, C. M. T., Scofield, S. R. Kim, H. S., Lavelle, D. T., Dahlbeck, D., and Staskawicz, B. J. 1996. Tomato Prf is a member of the leucine-rich repeat class of plant disease resistance genes and lies embedded within the Pto kinase gene cluster. Cell 86:123-133.

Schultz, J., Milpetz, F., Bork, P., and Ponting, C. P. 1998. SMART, a simple modular architecture research tool: signaling domains. Proc. Natl. Acad. Sci. U.S.A. 95:5857-5864

Scofield, S. R., Tobias, C. M., Rathjen, J. P., Chang, J. H., Lavelle, D. T., Michelmore R. W., and Staskawicz, B. J. 1996. Molecular basis of gene-for-gene specificity in bacterial speck disease of tomato. Science 274:2063-2065.

Scutt, C. P. 1997. Differential Screening. Pages 1-22 in: Differentially Expressed Genes in Plants: A Bench Manual. E. Hansen and G. Harper, eds. Taylor \& Francis, Bristol, PA, U.S.A.

Shan, L., He, P., Zhou, J., and Tang, X. 2000. A cluster of mutations disrupt the avirulence but not the virulence function of AvrPto. Mol. PlantMicrobe Interact. 13:592-598.

Snead, M. A., Alting-Mees, M. A., and Short, J. M. 1997. cDNA library construction for the Lambda ZAP based vectors. Pages 39-51 in: cDNA Library Protocols. C. A. Cowell and C. A. Austin, eds. Humana Press, Towowa, NJ, U.S.A.

Song, W. Y., Wang, G. L., Chen, L. L., Kim, H. S., Pi, L. Y., Holsten, T., Gardner, J., Wang, B., Zhai, W. X., Zhu, L. H., Fauquet, C., and Ronal, P. 1995. A receptor kinase-like protein encoded by the rice disease resistance gene, Xa21. Science 270:1804-1806.

Stahl, E. A., and Bishop, J. G. 2000. Plant-pathogen arms races at the molecular level. Curr. Opin. Plant Biol. 3:299-304.

Tang, X., Frederick, R. D., Zhou, J., Halterman, D. A., Jia, Y., and Martin, G. B. 1996. Initiation of plant disease resistance by physical interaction of AvrPto and Pto kinase. Science 274:2060-2063.

Torii, K. U. 2000. Recepor kinase activation and signal transduction in plants: an emerging picture. Curr. Opin. Plant Biol. 3:361-367.

van der Biezen, E. A., and Jones, J. D. G. 1998. Plant disease-resistance proteins and the gene-for-gene concept. Trends Biochem. Sci. 23:454-456.

van der Zwet, T., and Beer, S. V. 1999. Fire blight-Its nature, prevention and control: a practical guide to integrated disease management. Agric. Inf. Bull. No. 631. United States Department of Agriculture, Washington, D.C.

White, F. F., Yang, B., and Johnson, L. B. 2000. Prospects for understanding avirulence gene function. Curr. Opin. Plant Biol. 3:291-298.

Zhou, J., Loh, Y., Bressan, R. A., and Martin, G. B. 1995. The tomato gene Ptil encodes a serine/threonine kinase that is phosphorylated by Pto and is involved in the hypersensitive response. Cell 83:925-935.

\section{AUTHOR-RECOMMENDED INTERNET RESOURCES}

National Center for Biotechnology Information web site: www.NCBI.nih.gov/BLAST

SMART (Simple Modular Architecture Research Tool) website: smart.embl-heidelberg.de

The ExPASy (Expert Protein Analysis System) Prosite webpage: www.expasy.ch/Prosite

\section{Erratum}

Genbank accession numbers given on page 55 were incorrect and were revised online on February 6, 2006. 